\title{
TEACHING READING NARRATIVE TEXT USING THINK PAIR SHARE (TPS) TECHNIQUE IN CLASS VIII SMPN 03 CIMAHI
}

\author{
Witri yunarti ${ }^{1}$, Yuliyanti ${ }^{2}$, Isry laila syathroh ${ }^{3}$ \\ ${ }^{1}$ IKIP Siliwangi \\ ${ }^{2}$ IKIP Siliwangi \\ ${ }^{3}$ IKIP Siliwangi \\ ${ }^{1}$ witriydaeli@gmail.com, ${ }^{2}$ yuliantisakurasparkyu@gmail.com, ${ }^{3}$ islaisya@yahoo.com
}

\begin{abstract}
Reading is something important and necessary for students because the achievement of their study depends on the greater part of their ability to read. The aims of the researchers is to investigate the application of Think Pair Share (TPS) technique to improve students reading comprehension. The population were 140 students of class VIII in SMPN 03 Cimahi. The researchers used quantitative method. The instrument that the researchers used are observation, field note, pretest and posttest. The result of this study proved that the Think Pair Share (TPS) technique is effective to be used in learning reading narrative text. The result showed that statistic calculation the mean scores of pretest is 63.43 and the mean scores of posttest is 83.57. So it can be concluded that after students learned reading narrative text using Think Pair Share (TPS) technique, their reading abilities are improved.
\end{abstract}

Keywords: Think Pair Share, Reading Skill, Quantitative Method

\section{INTRODUCTION}

Reading play an important role in people's lives. Some experts state that though reading, people can open the window of the world. This means that though reading, various important information arquand the world ca be know. Reading is one of the receptive skills, besides the listening skill. According to Zwiers (2004: 3) as cited in Parmawati (2018), reading habits more clearly describes the automatic and unconcious process that are involved in constructing meaning from text.Reading is a fluent process of readers attaching information from a text and their own background knowledge to build meaning (Wahyuni, 2009). It means that when learners read a text, they combine their knowledge and information that is gotten from the text.

Besides, reading also offers large amount of language input for the students. In reading, students will learn how to arrange the words, how to use words in a sentence appropriately, or how to write well. It also helps them to develop their vocabulary mastery and spelling. Reading give a major boost to metalinguistic awareness. Metalinguistic awareness is a skill to treat language as an object detach from the meaning it transfers (Lightbown \& Spada, 2006). Unfortunately, reading a second language text is not that easy, this difficulty is caused by many factors, either from the students itself or the teacher (Patel \& Jain, 2008). It is in line with many research results that indicated the ability of Indonesian students to read English texts was very low (Hamra, 1993 and 1996; Mardiana, 1993; Kweldju 2001 cited in Apsari \& Yana, 2015). 
A narrative is a piece of text which tells a story and, in doing so, entertains or informs the reader or listener (Setiyaningsih, 2013). She also states that the significant lexicon grammatical countenances of narrative texts are: focus on definite and usually individualized participants; use of material process; use of comparative process and mental process; use of temporal conjunctions; and the use of past tense. In conclusion, the purpose of narrative text is to amuse the reader with certain or vicarious experience in different ways which have generic structure of orientation, complication, resolution and re-orientation.

Narration is the telling of a story, either fictional or real whose subject is an incident or a series of related incident. As narrative fiction includes every kind of story from the sort tale to the long novel, so non fictional narrative includes every kind of story from the short anecdote to the book length account of a long series of incidents (Inman\& Gardner,1964). Another definition of narrative text is essays whose main target is acts of deeds woven and arranged into an event that takes place in a unit of time. Or it can also be formulated in other ways; narrative is a form of essay that tries to describe as clearly as possible to the reader an event that has occurred (keraf, 1987).

From the description above, researchers were interested in improving students reading skill in order to comprehend a narrative text. The appropriate technique is important in teaching and learning process, because it can create the effective teaching and learning process and impact the students' improvement. The researchers choose Think Pair Share (TPS) technique because according to the experts, it can improve the students' ability in reading to comprehend a narrative text.

TPS is developed to encourage students' participation in the classroom activities (Lyman, 2005: 1) in Mundriyah and Parmawati (2016). Think Pair Share (TPS) technique is a cooperative learning technique that motivate students' participation and is benefit for all year level and class size and is particularly useful in making

Lectures interactive.

There several process of Think Pair Share (TPS) technique in the classroom:

1. Teacher proses a question

The process of think, pair, share starts at the teacher process a thought-provoking question for the entire class. This may be a straightforward question or a problem the teacher wants to pose to the class for solution.

2. Students think individually

At a signal from the teacher, students are given a limited amount of time to think of their own answer to the problematic question. The time should be decided by the teacher on the basis of knowledge of the students, the nature of the question, and the demands of the schedule. It may be helpful, though it is not required, to have students write out their individual responses and solutions. Students should understand that while there may be no one up with some reasonable answer to the question. This step of the procedure automatically builds "wait time" into the classroom conversation.

3. Each student discusses his or her answer with a fellow student

The end of the think step signals to the students the time to begin working with one other student to reach consensus on an answer to the question. Each student now has a chance to try out possibilities. Together, each pair of students can reformulate a familiar answer based on their collective insight to possible solution to the problem. At times, 
the process can go one step further by asking pairs of students to regroup into four students to further refine their thought before sharing with the group at large. These small group settings are less threatening to individual students than dealing forward before the whole group with an unproved answer. The pair stage in the model also develops much more conversation among students about the problem entailed by the question.

4. Students share their argues with the others students

In this final step, individual can present solving individually or cooperatively to the class as a whole group. Where pairs of students have built up displays of their argues, as in a chart or diagram, each member of the pair can take credit for the product their thinking. The final stage of think, pair, share has several benefits to all students. They see the same concepts expressed in several different ways as different individuals find unique expressions for answers to the question.

The use of strategy Think Pair Share (TPS) technique: The teacher decides upon the text to be read and develops the set of questions or prompts that target key content concept. The teacher then describes the purpose of the strategy and give the guidelines for discussions. As with all strategy direction, teachers should model the procedure to establish that students understand how to use the strategy. Teacher should guide and support students as they work.

\section{METHOD}

Quantitative method was used in this study. The researchers used the quasi-experimental design which is a naturally assembly groups as intact classes or sample which may be similar (Cohen, Manion, \& Moririson, 2007). This design used pretest and posttest to the participant in the class. The research implements Think Pair Share (TPS) technique in the class. This study focuses on giving treatment to experimental class by applying Think Pair Share (TPS) technique in teaching reading narrative text, and then the research observes the result through classroom observation and test (pretest and posttest) in order to find out whether or not Think Pair Share (TPS) technique is effective on students reading in narrative text. The researcher will take population for the research of teaching reading narrative text. There are eleven classes in the eighth graders in SMPN 03 Cimahi, and the researcher took one class in eight graders in SMPN 03 Cimahi as the sample.

\section{RESULTS AND DISCUSSION}

Before giving treatment, the researchers gave a pre-test and after the treatment, the researcher gave a post-test. So, the students' scores were got from: 1) pretest score 2) posttest score. Table 1 below shows the result of pretest and post test of the participants:

Table 1: Scores of Pretest and Post Test

\begin{tabular}{lrrrr}
\hline Std & pretest & posttest & SMI & N-Gain \\
\hline std 1 & 65 & 65 & 100 & 0.00 \\
\hline std 2 & 75 & 85 & 100 & 0.40 \\
\hline std 3 & 55 & 60 & 100 & 0.11 \\
\hline std 4 & 55 & 70 & 100 & 0.33 \\
\hline std 5 & 70 & 75 & 100 & 0.17 \\
\hline std 6 & 75 & 75 & 100 & 0.00 \\
\hline std 7 & 80 & 85 & 100 & 0.25 \\
\hline
\end{tabular}




\begin{tabular}{lrrrr}
\hline std 8 & 70 & 80 & 100 & 0.33 \\
\hline std 9 & 55 & 75 & 100 & 0.44 \\
\hline std 10 & 65 & 75 & 100 & 0.29 \\
\hline std 11 & 70 & 80 & 100 & 0.33 \\
\hline std 12 & 65 & 70 & 100 & 0.14 \\
\hline std 13 & 65 & 75 & 100 & 0.29 \\
\hline std 14 & 70 & 75 & 100 & 0.17 \\
\hline std 15 & 70 & 70 & 100 & 0.00 \\
\hline std 16 & 65 & 70 & 100 & 0.14 \\
\hline std 17 & 60 & 70 & 100 & 0.25 \\
\hline std 18 & 65 & 70 & 100 & 0.14 \\
\hline std 19 & 60 & 70 & 100 & 0.25 \\
\hline std 20 & 55 & 60 & 100 & 0.11 \\
\hline std 21 & 50 & 55 & 100 & 0.10 \\
\hline std 22 & 60 & 65 & 100 & 0.13 \\
\hline std 23 & 75 & 80 & 100 & 0.20 \\
\hline std 24 & 60 & 70 & 100 & 0.25 \\
\hline std 25 & 55 & 60 & 100 & 0.11 \\
\hline std 26 & 60 & 65 & 100 & 0.13 \\
\hline std 27 & 75 & 85 & 100 & 0.40 \\
\hline std 28 & 55 & 60 & 100 & 0.11 \\
\hline std 29 & 50 & 55 & 100 & 0.10 \\
\hline std 30 & 60 & 75 & 100 & 0.38 \\
\hline std 31 & 50 & 55 & 100 & 0.10 \\
\hline std 32 & 60 & 65 & 100 & 0.13 \\
\hline std 33 & 55 & 65 & 100 & 0.22 \\
\hline std 34 & 60 & 70 & 100 & 0.25 \\
\hline std 35 & 70 & 75 & 100 & 0.17 \\
\hline Total & 2205 & - & - & - \\
\hline Mean & 63.43 & 83.57 & - & 0.19 \\
\hline Stadev & 8.06 & 8.35 & - & 0.00 \\
\hline Max & 80 & 85 & - & 0.25 \\
\hline Min & 50 & 55 & - & 0.10 \\
\hline & & & & \\
\hline
\end{tabular}

The result showed that statistic calculation above the mean scores of pretest is 63.43 and the mean scores of posttest is 83.57. So it can be concluded that after students learned reading narrative text using Think Pair Share (TPS) technique, their reading skills are improved. The result of this study proved that the Think Pair Share (TPS) technique is effective to be used in learning reading narrative text.

\section{CONCLUSION}

In conclusion, the implementation of Think Pair Share (TPS) technique is effective to help students to increase comprehension in learning reading narrative text. Since most of them asked questions, answered the questions given by the researchers and made some notes. Besides, Think Pair Share (TPS) also can improve the criterion of minimum completion or Kriteria Ketuntasan Minimal (KKM) in reading skill. It can be known from the result of the scores test.

From the result of this study proved that the Think Pair Share (TPS) technique is effective to be used in learning reading narrative text. The result showed that statistic calculation the mean scores of pretest is 63.43 and the mean scores of posttest is 83.57. So it can be concluded that 
after students learned reading narrative text using Think Pair Share (TPS) technique, their reading abilities are improved. Thus, using Think Pair Share method can improve students reading skill on narrative text at SMPN 03 Cimahi.

\section{ACKNOWLEDGMENTS}

All praises be to Alloh, the Lord of the world who has given the Mercy and Blessing upon the researchers in completing this journal. Peace and salutation be upon the prophet Muhammad SAW, his family and his companion, and his adherence.

It is a pleasure to acknowledge the help and benefaction to all lecturer institution, family and friends who have contributed in different ways hence this research paper is processed until it becomes a complete writing which will be presented to the faculty of Ikip Siliwangi in partial fulfilment of the requirements for the bachelor of education degree of S.Pd (S-1) in English language education.

\section{REFERENCES}

Cohen, L, Manion, L., \& Moririson. (2007). Research methods in Education.London: Routledge

Inman, B. A. \& Gardner. (1964). Aspect of communication. New York: Second Edition

Keraf. (1987). the difficulties of english teacher in instilling character building through narrative stories at elementary schools in central java, indonesia. 136. Ende Flores: Nusa Indah

Lightbown, P.M \& Spada, N. (2006). the role of reading in language learning. Oxford: Oxford University Press.

Mundriyah, M., \& Parmawati, A. (2016). Using Think-Pair-Share (Tps) To Improve Students'writing Creativity (A Classroom Action Research In The Second Semester Students Of Stkip Siliwangi Bandung). P2m Stkip Siliwangi, 3(2), 84-91.

Parmawati, A. (2018). The Study Correlation Between Reading Habit And Pronunciation Ability At The Second Grade Students Of Ikip Siliwangi. Eltin Journal, Journal Of English Language Teaching In Indonesia, 6(1), 46-52.

Patel, M.E., Jain, P. . (2008). English language teaching (methods, tools, \& technique). Jaipur: Sunrise Publisher \& Distributor

Setiyaningsih, A. (2013). Journal of English Language Teaching. 2(2), 1-8. Available at (http://www.language-teaching.org/) accesed on july 172019.

Wahyuni, (2009) . Using think pair share method to improve the reading skill on narrative text of the students of MTSN kunir Blitar.97-111. Available at (http://www.readingnarrative-text.org/). 